\title{
Creationism in Europe: facts, gaps and prospects
}

Stefaan Blancke ${ }^{1, *}$, Hans Henrik Hjermitslev ${ }^{2}$, Johan Braeckman $^{1}$, Peter C. Kjærgaard ${ }^{3}$

${ }^{1}$ Ghent University, Department of Philosophy and Moral Sciences, Blandijnberg 2, 9000 Ghent, Belgium

${ }^{2}$ University College South Denmark, Dr. Margrethes Vej 11-13, 6200 Aabenraa, Denmark

${ }^{3}$ Aarhus University, Interdisciplinary Evolutionary Studies, Department of Culture and Society, Jens Chr. Skous Vej 7, 8000 Aarhus C, Denmark

"* corresponding author, st.blancke@gmail.com

\section{Acknowledgments}

The research for this paper was funded by Ghent University (BOF 08/24J/041) and the Carlsberg Foundation (grant no. 2008_01_513). We would like to thank Barbara Forrest, Ronald L. Numbers and the two anonymous referees of the JAAR for their helpful remarks

\begin{abstract}
The purpose of the paper is threefold. First, we present and discuss the extant literature on creationism in Europe (the "facts"). Within this section, we offer a review of the literature as well as an overview of the most remarkable developments and events recorded therein. Second, we indicate which material is missing from the literature (the "gaps") and signal which gaps we think should first be filled. And third, on the basis of a forthcoming international historical study, we outline the possible factors that affect the popularity of creationism in Europe (the "prospects"). We also sketch how a sustained study of European creationism can contribute to other research domains such as the study of cultural evolution and the relation between science and religion.
\end{abstract}

\section{Keywords}

Creationism - Europe - anti-evolutionism - fundamentalism - religious activism - science and religion

\section{Introduction}

Creationism has often been considered a socio-religious phenomenon, typical of the United States. In an interview he gave in 2001, the late Stephen Jay Gould labelled creationism a "local, indigenous, American bizarrity," which was in line with the view Richard C. Lewontin offered in 1983, claiming that "creationism is an American institution, and it is not only 
American but specifically southern and southwestern" (both in Numbers 2009: 215).

However, although the popularity of creationism has indeed reached unparalleled heights in the United States, historical and sociological research conducted over the last two decades has decisively shown that creationism has broken from its original theological and geographical confines to become a global issue. Creationist activities have been reported from Canada to Korea, from Brazil to Australia (Numbers 2006, 2009). As an increase of creationist activities has also been noted in Europe, a growing number of European scholars, including the authors of this paper, have taken a serious interest in the subject. The material available is scattered geographically and often written in local languages, making difficult an overview of the studies of creationism in Europe. A comprehensive literature review is thus much needed.

In light of the above, this paper serves three purposes. First, we present and discuss the extant literature on creationism in Europe (the 'facts'). Within this section, we offer a review of the key literature sources and summarize the most remarkable developments and events recorded therein. Second, we indicate the material absent from the literature (the 'gaps') and highlight the gaps that should, in our view, be addressed as a priority. Third, based on a forthcoming international historical study edited by three of the authors, we outline the factors that affect the popularity of creationism in Europe, which we predict, will continue to do so in the future (the "prospects"). We also sketch how a study of European creationism can contribute to other research domains, such as the study of cultural evolution and the relation between science and religion.

\section{The facts}

\section{Historical studies}

The origins of and developments within American creationism have been the subject of many historical studies. Ronald Numbers' seminal The Creationists: From Scientific Creationism to 
Intelligent Design (2006) traces the historical roots of creationism to the second half of the $19^{\text {th }}$ century. However, there are several other studies that provide a detailed picture of the history of American creationism (e.g., Forrest and Gross 2007 [2004]; Larson 2006). In comparison, historical studies of creationism in Europe are rather scarce. Arthur McCalla (2006), for example, traces the origins of the contemporary creation-evolution debate back to earlier discussions involving the relation between science and religion in $17^{\text {th }}$ and $18^{\text {th }}$ century Europe. However, with a few exceptions, such as Abraham C. Flipse's study (2012) of the origin of Dutch creationism, as of this writing, no studies that explicitly treat the history of modern European creationism before the 1970s have been conducted. Furthermore, Martin Riexinger (2010) studied anti-evolutionism in the Islamic world, including Turkey. This does not mean that anti-evolution sentiments and movements were absent in Europe. Some Scandinavian Protestants, for example, were challenging the theory of evolution in the early decades of the twentieth century (Hjermitslev 2011). In the 1920s, the anthropologist Sir Arthur Keith was warning against a rise of creationism in Britain. Shortly after, in 1932, the Evolution Protest Movement was founded in London, allegedly as the first of its kind in the world, with Sir Ambrose Fleming as its first president (Numbers 2006: 141-144). Generally, historical studies have insufficiently dealt with the lives of actors or the history of organizations involved with creationist activism, offering instead rather brief overviews of people, organizations and most significant events involving European activist creationism in the last ten to fifteen years. Ulrich Kutschera (2003), Almut Graebsch and Quirin Schiermeier (2006), Athel Cornish-Bowden and María Luz Cárdenas (2007), Peter Kjærgaard (2008) and Ronald Numbers $(2006,2009,2011)$ are the most prominent examples of such studies. An interesting overview of creationist events in several European countries can also be found in the working document proceeding the Council of Europe resolution 1580 (Committee on Culture 2007) that warned against "the dangers of creationism for education" in October 2007 
(Parliamentary Assembly of the Council of Europe 2007). Creationism in Turkey was already being discussed at length in the 1990s (Edis 1994, 1999; see also: Edis 2007; Hameed 2010; Riexinger 2008; Sayin and Kence 1999), as was creationism in the UK (Coleman and Carlin 1996). However, more detailed studies have recently become available, discussing creationism in Germany (Kutschera 2008a, 2008b), the United Kingdom (Williams, 2008), Russia (Levit, Hoßfeld and Olsson 2007), Poland (Borczyk 2010), Denmark (Hjermitslev 2010a) and the Netherlands (Blancke 2010, Flipse 2012).

In terms of the main actors, organizations and events, there is a certain overlap in the literature on creationism in Europe. Some of these publications have become standard references in public and scholarly discussions of the issue. Still, we find useful a brief recount of some of the more recent episodes of European creationist activism. Mostly, creationist strategies aim at influencing educational policy, either at a local, national, or even at a European level, demanding that equal time is dedicated to creationism and evolution, or the complete removal of evolutionary theory from science education. For instance, in early 2002, newspapers reported that Emmanuel College, an independent school in Gateshead, England, had rented out its facilities to the organizers of a creationist conference featuring Ken Ham, the president of the largest young-earth creationist organization, Answers in Genesis. However, following this minor event, a newspaper also reported that at Emmanuel College creationism was taught as an alternative to evolutionary theory. Although the Emmanuel Schools Foundation sponsoring the school denied these allegations, at least two of the school's staff, the Head of Science and the First Principal, were well-known young-earthers and proponents of an equal time policy (one of them actually admitted that he preferred the exclusive teaching of creationism, but was willing to settle for equal time). When MPs asked Prime Minister Tony Blair about the teaching of creationism in (partly) state-funded schools, he responded by referring to the outstanding results of the school, claiming that the reports of 
creationism were exaggerated and that education benefits from diversity (Allgaier 2010; Allgaier forthcoming; Allgaier and Holliman 2006; Cornish-Bowden and Càrdenas 2007; Gross 2002; Kutschera 2003; Numbers 2006; Williams 2008). Another important creationist event in the UK took place in 2006, when the recently founded creationist pressure group Truth in Science published two DVDs promoting intelligent design, which were distributed to every secondary school in the UK. In an immediate response, the Ministry of Education claimed that it did not endorse the use of such material in science classes. The British Centre for Science Education was soon founded to monitor creationist activities in the UK and was tasked with meeting creationist activities with expedient and apt response (Graebsch and Schiermeier 2006; Williams 2008).

In Germany, a somewhat similar incident occurred in 2006, when it was reported that creationism was taught at two schools in Giesen, a town in the state of Hesse. However, instead of explicitly condemning such educational practices, as was the case in the UK, the Minister of Education of the state, Karin Wolff, sided with the schools in opining that creationism should be taught in biology classes, along with evolutionary theory (CornishBowden and Càrdenas 2007; Graebsch and Schiermeier 2006). Also in Germany, the creationist organization Wort und Wissen (Word and Knowledge), published a creationist biology textbook entitled Evolution: Ein kritisches Lehrbuch (Evolution: A critical textbook), written by theologian Reinhard Junker and microbiologist Siegfried Sherer. The book has been translated into several European languages, including Portuguese, Finnish, Russian and Dutch, and was awarded a German textbook prize (which was sponsored by religious conservatives). Since then, it has been used in at least some German public schools as a supplement to the authorized textbooks (Kutschera 2003, 2008b; Numbers 2006). In Russia, in line with almost every other eastern European country, both local and foreign activist creationists have seized the opportunities that arose after the fall of communism in 1989. 
While American creationists soon exported their beliefs to the region, some events reveal a more indigenous form of creationism. In 2006, a fifteen-year-old girl and her parents filed a complaint to the court in St. Petersburg, demanding freedom of choice, claiming that her religious beliefs were violated by the teaching of evolutionary theory. This action was supported by both the Russian Orthodox Church and the Russian Minister of Education, who both claimed to welcome the teaching of alternative ideas. In February 2007, however, the case was turned down (Levit, Hoßfeld and Olsson 2006, 2007). In Scandinavia, organised creationist movements did not emerge before the 1980s, when creationist groups and individuals in Sweden, Norway and Denmark began to cooperate. In 1983, evangelical antievolutionists from Norway and Denmark launched the journal Origo, prompting the Scandinavian creationist groups to the right of the Protestant theological spectrum to join forces in translating books, organising networks and conferences and building up websites such as skabelse.dk and genesis.nu. In 1996, a creationist museum was established in Umeå, Sweden, and in 2009, the Darwin anniversary year, Norwegian and Danish anti-evolutionists generated some media attention by registering polemic anti-Darwinian websites. During the last few years, Muslim old-earth creationists and Vedic intelligent design advocates have also entered the Scandinavian scene through websites, lectures, media appearances and publications (Hjermitslev 2010a, 2010b; Kjærgaard 2010; on Hindu responses to Darwinism, see Mackenzie Brown 2010). ${ }^{1}$

These episodes indicate that activist creationism in Europe, both local and imported, is a phenomenon to be reckoned with. Many of the incidents involve government ministers who not only condone creationist teaching, but also actively support it. Tony Blair, for example,

\footnotetext{
${ }^{1}$ Young-earth creationism is the belief that a supernatural being created the earth six- to ten thousand years ago. Old-earth creationists reconcile their belief in sudden divine creation with the scientific evidence for a much older earth.
} 
never spoke forcefully against the teaching of creationism (Williams 2008), and in Hesse, the minister of education expressed her sympathy with the creationist call for equal time devoted to it in education. In the Netherlands, the Minister of Education, Science and Culture, Maria van der Hoeven, a Catholic member of the Christian Democratic Party (CDA), suggested that intelligent design could be "applied in schools and classes" (translated quote in Blancke 2010: 793). In some countries, however, the political support went much further. In Italy, in 2004, for instance, the minister of education and research in the Berlusconi government, Letizia Moratti, planned the removal of evolutionary theory from education for 11- to 14-year-olds (Graebsch and Schiermeier 2006; Numbers 2006). In 2005, the Romanian ministry of education allowed teachers in both public and Christian schools to opt for a creationist alternative to the biology textbook (Numbers 2006). In Serbia, the minister of education, Ljiljana Colic, had to resign after she had declared in 2005 that educators should not teach evolutionary theory if creationism was not also included (Committee on Culture 2007; Numbers 2006). In both Russia and Ukraine, the ministry of education cosponsored creationist conferences (Numbers 2006) and in Poland, the deputy minister of education, the ultra-Catholic Miroslaw Orzechowski, professed in 2006 that " $[\mathrm{t}]$ he theory of evolution is a lie. It is an error we have legalized as a common truth." He also considered evolution to be the "feeble idea of an aged non-believer" and claimed that Darwin was "a vegetarian and lacked fire inside him" (quoted in Kjærgaard 2008: 40). These events clearly demonstrate that, although creationist activism is not as evident in the public sphere as in the United States, creationist groups, at least in some of the European countries, are able to exert (or even gain) sufficient power to attempt to influence national educational policy.

Even at a more general European level, creationist lobbying is now part of the political reality. For example, in 2007 in Strasbourg, France, the decision over the resolution that warns against the dangers of creationism came to a surprisingly close vote after intense 
lobbying by the Vatican and the European Evangelical Alliance (Curry 2009; Hjermitslev 2010a). In October 2006, a seminar entitled "Teaching evolutionary theory in Europe: Is your child being indoctrinated in the classroom?" was held in Brussels for the members of the European Parliament. The seminar was organized by the Polish Catholic creationist Maciej Giertych and featured three antievolutionists (Kutschera 2006).

The closest European collaboration, however, between state and activist creationist groups took place in Turkey, where, in 1985, the government contacted the young-earth creationist Institute for Creationist Research (ICR) with a request for educational material. Books of prominent ICR members, including Henry Morris' Scientific Creationism, were translated into Turkish (with the omission of explicit Biblical references) and distributed free of charge to every secondary school teacher in the country. Moreover, the religiously most controversial aspects of evolutionary theory, the simian origin of man and the mechanism of natural selection, were deleted from biological textbooks. In the 1990s, conservative politicians with creationist sympathies lost momentum. Under a social democratic government, biology textbooks were revised, although they still offered creationist views as an alternative theory. Today, the way creationism and evolution are treated in textbooks very much depends on the type of government in power. In 2002, the moderately Islamic Justice and Development Party (AKP) came into power, thus creating a favourable environment for Adnan Oktar and his followers from the Science Research Foundation (BAV). Oktar, an interior designer best known under his pen name Harun Yahya, has also borrowed much of the material from ICR with which the BAV actively sought cooperation (Edis 2007; Riexinger 2010: 495). Taner Edis (2007: 128) succinctly describes Yahya's creationism as a: "grab bag of classic Islamic objections to evolution, arguments copied directly from Christian youngearth creationists and intelligent design proponents, and other snippets from western writers who claim to find signs of God in some area or other of modern science." 
However, Oktar has managed to reframe the Protestant creationist content as an attractively modern version of Islamic creationism, targeted at urban professionals who wish to reconnect with their Islamic roots. By promoting his message through glossy books, slick magazines, DVDs and, in particular, the Internet (Kjærgaard 2008; Riexinger 2008), using modern Turkish language (without any Arabic elements), and endorsing the modern lifestyle, Oktar is clearly looking for support beyond the old creationist constituency of religious conservatives (Edis 2007). Remarkably, his activities have not been confined to Turkey. The books of Harun Yahya have been translated into a number of European (but also other) languages, including English, Dutch, French, German, Danish, Russian, Italian, Spanish, Polish, Albanian, Estonian, and Bulgarian. His teachings are particularly attractive to Islamic youth living in West-European cities, many of whom indulge in a modern Western lifestyle, while condemning Western morals for being secular, materialistic and individualistic. To these young adults, Oktar's organization offers the perfect deal. Oktar and his group have been particularly good at drawing media attention. In the course of 2006 and 2007, universities, secondary schools, journalists, clergymen, politicians and scientists in many European countries — including France, Belgium, Spain, Denmark, Switzerland and the UKwere sent unsolicited copies of the first and second volumes of the Atlas of Creation, an almost 800-page — lavishly produced publication in which evolutionary theory is "exposed" as a hoax and a dangerous doctrine that inspired the terrorist act of 9/11 and a host of other evil events. In addition, in at least France, Germany and Denmark, Oktar's affiliates have been active in manipulating online web polls on evolution and creationism in order to create an impression that the European public has rejected evolutionary theory after reading the Atlas of Creation. Therefore, it comes as no surprise that the Committee for Culture, Science and Education of the Council of Europe devoted special attention to Oktar's efforts when 
preparing the working documents that would eventually result in resolution 1580 (Committee on Culture 2007; Kjærgaard 2008, 2010).

As we have seen, Islamic creationism is not the only type of anti-evolutionism with which Europe has been confronted. The Protestant variant has proved particularly popular among evangelicals and in orthodox reformed communities in the UK, the Netherlands, Germany and Switzerland, counting some of the most active creationists among its members. Important incidents inspired by Catholic creationism took place in Poland, France and Italy, with several occurring in Russia and Serbia, as a result of Orthodox creationism. Although many of these creationist actions have begun as the result of proselytizing efforts by the large American young-earth organizations ICR and Answers in Genesis, there is a considerable proportion of "native" or "local" creationism, which American-style creationism is sometimes able to exploit, but not always, or at least, not entirely. In fact, the young-earth creationism and flood geology proclaimed by Americans are almost never accepted without being adjusted and adapted to local needs. For instance, with no First Amendment in a written constitution by which the teaching of biblical creationism is prohibited as in the United States, European creationists often find it superfluous to disguise their beliefs as creation science. ${ }^{2}$ The capacity to adapt to local religious and social environments might be considered one of the strengths of European creationism. However, not all soil has proven equally fertile. In the Netherlands, intelligent design creationism has wedged itself in the subculture of the orthodox reformed and evangelical communities, rather than in secularist society, for which it was intended by American Intelligent Design proponents (Blancke 2010; Forrest and Gross 2007 [2004]).

\footnotetext{
${ }^{2}$ The Establishment Clause in the First Amendment to the US Constitution states that "Congress shall make no law respecting the establishment of religion."
} 
Sometimes, local creationists select only a small subset of the material that serves their particular local strategies, and in some heavily secularized countries, for instance Belgium (Blancke 2009) and Denmark (Hjermitslev 2010b), creationism, local or imported, has limited success, resulting in marked differences between countries in the frequency and intensity of creationist activism.

\section{Quantitative data}

In the United States, Gallup has repeatedly questioned the nation about their beliefs concerning the origin of the human species, by asking the following question: "Which of the following statements comes closest to your views on the origin and development of the human species?" [See Figure 1].

Which of the following statements comes closest to your views on the origin and development of human beings?

1) Human beings have developed over millions of years from less advanoed forms of life, but God guided this process, 2) Human beings have developed over millions of years from less advanced forms of life, but God had no part in this process, 3 ) God created human beings pretty much in their present form at one time within the last 10,000 years or so

\% Humans evolved, with God guiding

\% God created humans in present form

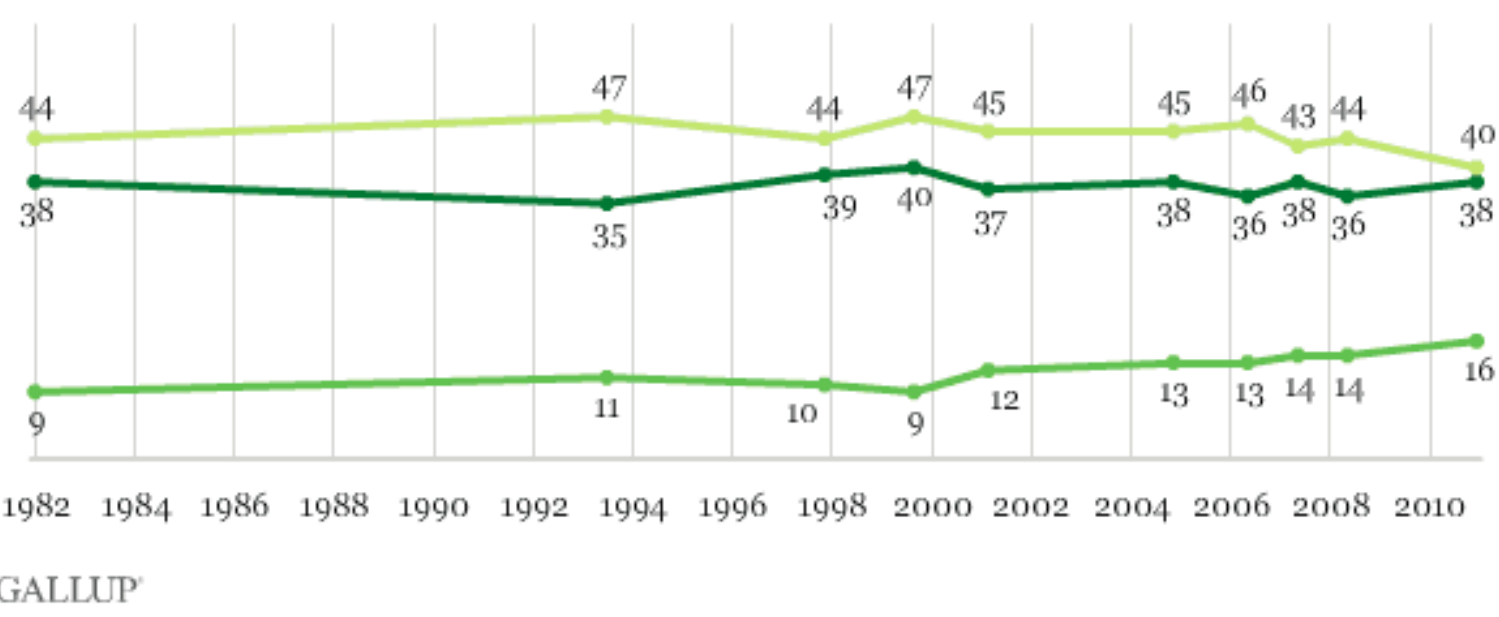

\section{Figure 1}

It is evident from Figure 1 that the figures have been relatively stable during almost thirty years, with consistently more than $40 \%$ of Americans supporting strict creationism, a little 
less than $40 \%$ believing that God guided human evolution, and 10 to $15 \%$ accepting "secular evolution". However, a small increase in the support of the last category at the expense of strict creationism has emerged more recently.

In Europe, such quantitative longitudinal studies are not available (as discussed below). However, there is sufficient material to provide some insight into the popularity and distribution of creationist beliefs in Europe. Moreover, unlike historical records, quantitative data provide unique opportunities to disclose more intuitive creationist beliefs that do not translate into activist creationism. For instance, Jon Miller et al. (2006) compared the results from surveys conducted in the United States with those of two surveys taken in Europe and one in Japan, in which respondents were asked whether they considered the statement, "Human beings, as we know them, developed from earlier species of animals" true or false. The results of this study, presented in a diagram (Figure 2), clearly indicate that human evolution is more readily accepted in European countries than in the United States, with the exception of Turkey (see below). However, it is often overlooked that even in the most evolution-friendly European states, the level of acceptance almost never exceeds $80 \%$. In fact, in most countries, no more than $70 \%$ of surveyed population accepts human evolution, whereas $20 \%$ rejects it. Although these figures are not as low when compared to the situation in the US, they do reveal that anti-evolutionism is far from absent in Europe. 


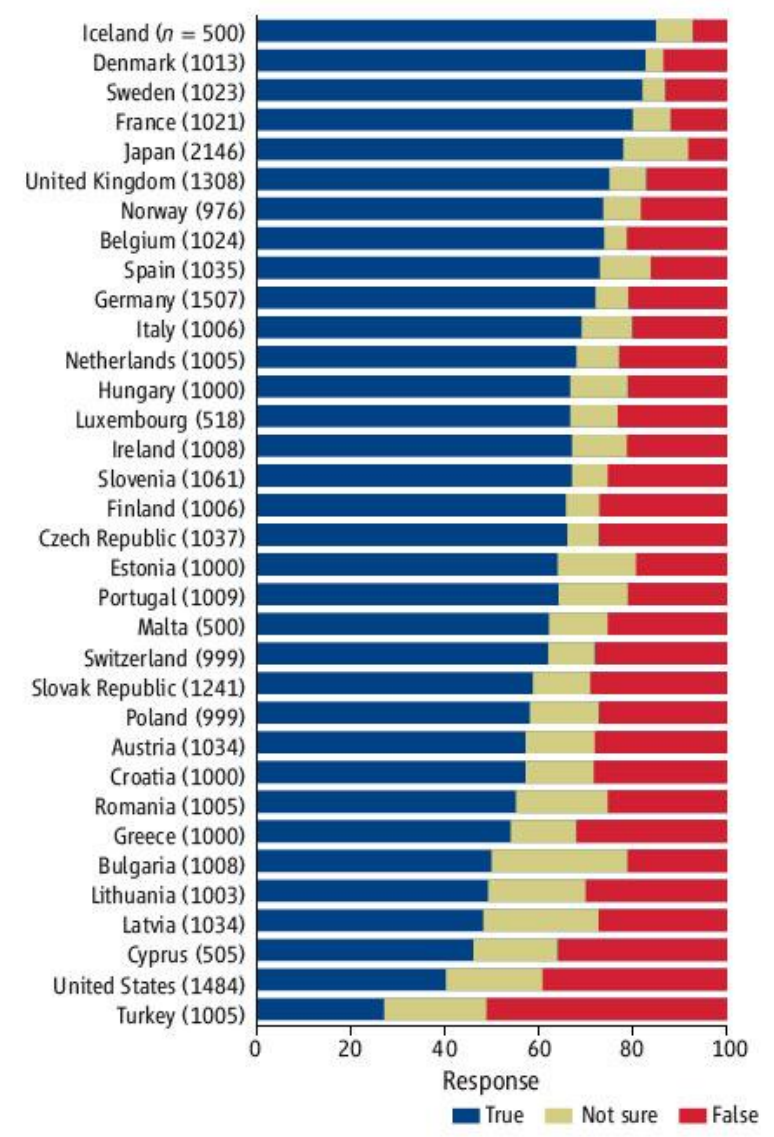

Public acceptance of evolution in 34 countries, 2005.

Figure 2

Part of the Miller study was based on data collected for the Eurobarometer that had been published a year earlier (European Commission 2005). This document included the same question Miller and colleagues asked in their study, reporting that, on average, $70 \%$ of respondents accepted human evolution, and 10\% either did not know or did not answer the question. Interestingly, it was noted that the acceptance among the New Member States was actually considerably lower, with only $60 \%$ of respondents accepting human evolution (European Commission 2005: 47). ${ }^{3}$ Indeed, a closer look at the Miller diagram reveals that generally, the acceptance rates in these countries are among the lowest.

\footnotetext{
${ }^{3}$ The new member states include the Czech Republic, Estonia, Hungary, Latvia, Lithuania, Poland, Slovakia, Slovenia, Malta and Cyprus.
} 
Less extensive, but still interesting surveys and polls have also been conducted elsewhere. In 2002, a Swiss professional company probed Europeans for their views on evolution. Only $40 \%$ of the respondents agreed that the universe, the earth and all life on it, had come about through natural processes. About $20 \%$ claimed to adhere to theistic evolution and the same percentage believed that God had created all organisms at one time within the last 10,000 years. The remaining $20 \%$ of those surveyed did not answer the question or stated that they did not know the answer (Kutschera 2003). In 2006, a BBC poll in the UK indicated that $48 \%$ of the surveyed population thought that evolution "best described their view on the origin and development of life." Creationism was the best description for $21 \%$ of the respondents, and intelligent design for 17\%, with $13 \%$ undecided (Numbers 2006: 408). In 2009, the British Council released the results of a survey on knowledge of and attitudes towards evolution in ten countries, including three European countries, Great Britain, Russia and Spain. One of the questions was "To what extent do you agree or disagree that enough scientific evidence exists to support Charles Darwin's theory of evolution?" In Great Britain, $62 \%$ of respondents agreed and $9 \%$ disagreed with this statement, in Russia, the response rates were $48 \%$ and $10 \%$ and in Spain $61 \%$ and $8 \%$, respectively. A significant number of survey participants did not provide an answer or replied that they did not know what the answer was - about 30\% in Spain and Britain, and $42 \%$ in Russia. In fact, to the question "Which of [the following views on origin of species] comes closest to your own view?" $38 \%$ of the Britons and the Spanish, and 32\% of the Russians replied that they accepted natural evolution, that is, without guidance by God. Based on these responses, combined with 18 $25 \%$ adherents of guided evolution and $13-18 \%$ creationists, the British Council concluded that "the majority of adults in Great Britain, Spain and Russia believe that life on Earth, including human life, evolved over time as a result of natural selection in which no God played a part" (British Council 2009). However, the same results could also be interpreted as 
indicating that in none of these countries is naturalistic evolution is accepted by more than $40 \%$ of the population, which leaves a rather big pool in which activist creationists can fish. A recent poll by Ipsos MORI in 23 countries, including ten European countries, found that $41 \%$ of the global population accepts human evolution, and that 1 in 3 individuals prefer the creationist account. Another 31\% did not know what to believe. Sweden (68\%), Germany $(65 \%)$ and Belgium (61\%) ranked among the highest concerning the acceptance of human evolution, with only $8-12 \%$ creationist. In Italy, Poland and Russia, however, the percentage of creationists increased to 21,25 and $34 \%$, respectively. Again, with $60 \%$, Turkey had the highest percentage of creationists in all European countries (Ipsos Global @ dvisory 2011).

Several other surveys are more closely related to science education and have probed for attitudes towards creationism and evolutionary theory among students and teachers. In September 2008 at a conference in Turkey, Pierre Clément et al. presented the results of an extensive survey that included 5,700 teachers in 14 countries ( 8 of which were European). The survey was part of a project with even broader scope that included 19 countries. The findings of this study not only revealed that creationist teachers form a significant majority in North-African countries, such as Tunisia and Morocco, but also that they are not uncommon in Romania (about 45\%), Cyprus and Portugal (between 15 and 30\%). In Italy, Finland and Hungary, 15 to $18 \%$ of non-biology teachers hold creationist beliefs, but this prevalence reduces to 3 to $6 \%$ for biology teachers. There are almost no creationist teachers in France and Estonia (Clément, Quessada, Laurent and Carvalho 2008). The most remarkable results of the project, summarized by Pierre Clément and Marie-Pierre Quessada in a letter to Science, were:

Creationist beliefs were more likely in those with greater belief in God or greater religious observance, regardless of religion. Biology teachers were more evolutionist than their colleagues in only half of the countries surveyed. 
The longer a teacher trained at a university, the greater the acceptance of evolutionist ideas. (Clément and Quessada 2009: 1644)

Two studies from the UK confirmed that not all teachers are well prepared to deal with creationist challenges in the classroom. Anna Cleaves and Rob Toplis (2007: 34) found that "some mentors hold misconceptions about the status of evolution by natural selection," which made the authors wonder "what alternative evidence they will accept and whether they would use ID materials in the classroom from the Truth in Science movement." Exactly this question was investigated by Conor McCrory and Colette Murphy (2009), whose study findings revealed that pre-service biology teachers in Northern Ireland were indeed highly susceptible to the propaganda in one of the Intelligent Design DVDs that had been distributed by Truth in Science. Not only did nine out of ten participants take the claims in the DVD at face value, but the same number also "perceived a legitimate scientific challenge to evolution. Less than one in ten challenged the claims in the DVD or was sceptical of its scientific credentials." (McCrory and Murphy 2009: 380).

Student attitudes pertaining to this issue have been studied as well. Peter Fulljames and Leslie Francis (2004) conducted a series of surveys with the aim to reveal attitudes of students in Kenya and Scotland towards science and Christianity. One of the main findings of this study was that in Scotland, scientism, which the authors defined as the conviction that science provides absolutely true knowledge, correlated with the view that Christianity was necessarily creationist; however, the same correlation did not hold in Kenya. The authors surmised that scientism makes Scottish students expect the same certainty in religious beliefs, whereas in Kenya, students simply take creationism for granted, "because they are not aware of alternative Christian interpretations of the Genesis creation stories" (Fulljames and Francis 2004: 172). According to the authors, the dissimilarity in the results reflects different cultures and attitudes towards creationism. 
In closing this section, let us take a brief look at the available data concerning Islamic creationism. Two surveys have been conducted in which Turks have been asked about their views on evolution and human origins (Hameed 2008). In the study conducted by Miller and colleagues (2006), only $25 \%$ respondents agreed to the statement that "[h]uman beings, as we know them, developed from earlier species of animals." Similarly, in a study by Riaz Hassan (2007) in seven Islamic countries, 22\% of Turkish adults agreed with Darwin's theory of evolution (see Figure 3).

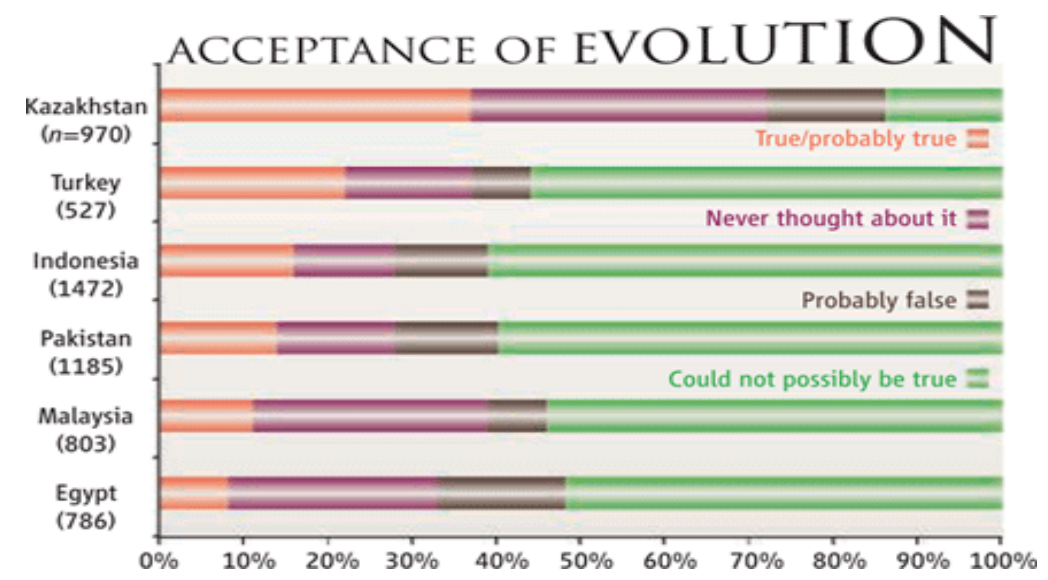

Figure 3

What conclusions can be drawn from these studies? Comparisons are hard to make because the surveys tend to probe for different issues connected with creationism. The Eurobarometer poll, for instance, is only related to an assessment of scientific literacy and consequently has little explanatory value concerning complex issues of science and religion and positions, such as young-earth creationism, intelligent design, theistic evolution and naturalistic evolution. The often cited Miller study published in Science compares results from different polls that are, in fact, not comparable, since they are based on different wordings and questions and do not distinguish between human evolution and evolution in general. They also fail to make the distinction between evolution and evolutionary theory. However, one rather obvious conclusion stands out: creationist beliefs are not equally distributed across the European continent. For instance, the inhabitants of eastern European countries and Turkey 
appear to be highly sympathetic to creationism, whereas in northern Europe, the large majority accepts evolution. Another conclusion is that the acceptance of evolution is much higher in Europe (with the exception of Turkey) than in the United States. These international and regional differences cry out for an explanation.

\section{Explaining creationism in Europe}

Of course, historical and quantitative studies are not just catalogues of creationists and their activities. They also attempt to explain creationism as a cultural phenomenon. Owing to the complexity of the subject, however, these studies tend to focus on accounting for different aspects of creationism in Europe. For instance, in one set of studies, the authors intend to explain why there are so many creationists, both activist and intuitive, in the United States as compared to Europe. Miller and colleagues (2006) applied quantitative methods in order to identify the factors that account for these different levels in creationism. Two factors emerged as particularly significant: widespread religious fundamentalism and the politicization of the debate over evolution - phenomena that occur in the United States, but not in Europe. Furthermore, one can add that in the United States, the famous Scopes or "monkey" trial in 1925 established anti-evolution as a permanent platform for evangelical fundamentalism (McCalla 2006). ${ }^{4}$ Bronislaw Szerszynski (2010) acknowledges that such quantitative approaches are valuable, but argues that they should be complemented with qualitative studies, since the former fail to yield an understanding of the individual differences in belief making. He refers to the sociological work of Raymond Eve and Francis Harrold (1991), who have put the creation/evolution debates in a much broader context of two competing

\footnotetext{
${ }^{4}$ The Scopes trial revolved around the young science teacher John T. Scopes who had been charged with violating the Tennessee Butler Act which stated that "it shall be unlawful for any teacher in any of the Universities, Normals and all other public schools of the State which are supported in whole or in part by the public school funds of the State, to teach any theory that denies the Story of the Divine Creation of man as taught in the Bible, and to teach instead that man has descended from a lower order of animals." (for more details on the Scopes trial, see Larson 2006).
} 
worldviews, which they termed 'cultural traditionalism' and 'cultural modernism'.

Szerszynski also mentions the cognitive approach taken by E. Margaret Evans (2000), who argues that the popularity of creationist beliefs can in part be explained by their appeal to some of our cognitive predispositions. Szerszynski focuses more on the different roles religion plays in order to account for the difference between the conditions in Europe, where liberal views on scripture dominate at least in the north-western countries, and in the United States, which is the hotbed of evangelical fundamentalism. As he puts it:

Organized religion in Europe, although in some ways weak, is nevertheless woven significantly into the lives of its constituent nations through binding symbols and rituals. By contrast, America's religious history was shaped by the experience of pilgrimage and revolution, and was characterized by the rejection of old churches and their hierarchies. (Szerszynski 2010: 162)

Unlike the lively religious marketplace in America, where denominations are competing and advertising their views in the media, the national churches in northern Europe play a very different, but nonetheless important role as primarily cultural institutions with strong symbolic meanings and as markers of key moments in people's lives. The wider scope of the national churches means that the religious focus is much more directed toward consensus and homogeneity than toward highlighting differences on controversial issues, such as evolutionary theory. Indeed, the role of the church or churches in society and in the lives of individuals seems to have a significant impact on the popularity of creationist beliefs.

Another important factor, according to Szerszynski, is that in Europe, education is more controlled at a national level than in the United States:

Such a context, in which diversity of opinion is contained within a broadly-democratic framework of shared beliefs and values, makes it far harder to promote unorthodox ideas in [European] schools, whatever views teachers or parents may hold individually. (Szerszynski 2010: 164) 
Other scholars agree that education has a considerable impact on the distribution of creationist beliefs, but they sometimes differ in the type of influence it exerts. Ulrich Kutschera (2008a) and Bartosz Borczyk (2010), for instance, argue that creationism in Europe is on the rise because of the fact that religious education, which is often funded by the state and sometimes even compulsory in European countries, is provided much earlier than science education, thus shaping a receptive audience for creationist beliefs. James Williams (2008) and Simon Locke (2004), however, see compulsory religious education in the UK as one of the possible reasons why creationist activism has not gained as much support in the UK as in the US. If religion is already being taught in schools, even in those funded by the state, there might be no reason for religious groups to challenge the policy of teaching evolution. Nevertheless, in some countries, including the UK and the Netherlands, the freedom religious education enjoys in state-sponsored schools, especially when compared to the US, has not always stopped creationist activists from demanding equal time for creationism or intelligent design in biology classes (Blancke 2010, Williams 2008). Locke (2004) agrees with Szerszynski (2010) in that the fact that most European education is under state control has a negative effect on the success of creationist beliefs. He assumes that the US educational system leaves public schools far more vulnerable to local and parental concerns, which is less the case when education is organized by the national government. Simon Coleman and Leslie Carlin (1996) argue that as religious education in the UK has more or less developed from Bible classes to a comprehensive introduction to the world's largest faiths, students' tolerance towards alternative religious viewpoints has increased, which, in turn, has dramatically reduced their sensibility to absolutistic claims. The fact that scholars attribute contrary effects to education, however, shows that the kind of impact of this variable depends very much on the specificities of the local context. In other words, while state-controlled education has the effect of hindering the dissemination of creationist beliefs in one cultural environment, it has the 
adverse effect in another. Therefore, understanding the distribution of creationism in a particular region or country, whether imported or local, active or intuitive, will require a solid analysis of the range of factors that constitute a particular cultural environment and their interaction with one another.

One other possible factor is the type of religion to which people adhere. In the United States, for instance, creationism is particularly popular among White evangelical and fundamentalist Protestants. However, the claim that religion has an effect needs some qualifying. Catholics in Lebanon and Burkina Faso are much more creationist than their fellow believers in Europe. Although the nature of religion does affect the popularity of creationism, frequency of religious practices appears to be even more significant. Other relative factors that constitute a particular cultural environment were the socio-economic development of a country, people's age (whereby younger individuals tend to be more creationist-oriented) and level of scientific training (Clément, Quessada, Laurent and Carvalho 2008). These findings imply that we need to be careful in making generalizations across religions, and that we need to take local or national factors into account as well.

Coleman and Carlin (1996) suggest that creationism is rather unsuccessful in the UK because the mainstream religious centre has softened considerably over the last decades. Bishops of the Anglican Church and the Archbishop of Canterbury have publicly rejected creationism and intelligent design (Allgaier, in press; Williams 2008). Moreover, conservative Christians have always formed a religious minority, which probably has made them more tolerant towards other religious views (Coleman and Carlin 1996). However, the fact that we need to be careful about generalizing across religions does not entail that the nature of religion has no effect whatsoever. Hans Hjermitslev (2010b) argues that in Denmark, mainstream Lutheranism has followed a theologically liberal, anti-literalist path, by which it opened up 
the intellectual space its followers needed in order to reconcile their faith with evolution. Abraham Flipse (2012) has documented how theological concerns drove the Dutch conservative Calvinists towards George McCready Price's flood geology in the 1930s, long before this became popular among American fundamentalists (Numbers 2006). In addition, according to Edis (2007: 120), it is not difficult for Muslim creationist activists to find a receptive audience because they "do not oppose the consensus of their own intellectual high culture. [...] Muslim creationists are insiders.”

Also important are the media through which creationist activists promote their religious views (Coleman and Carlin 1996, 2004). In the United States, it is rather easy for fundamentalists and evangelicals to establish their own television and radio stations and acquire a broadcasting license. In the United Kingdom, however, until fairly recently the BBC largely controlled television and radio, thereby severely restricting access to the media for creationists (Coleman and Carlin 1996). In fact, getting the BBC to devote time to their cause was one of the main concerns of British creationists during the 1970s (Numbers 2006: 362). The same applies to the opportunities creationist activists have to partake in the political process. In the United States, where the electoral system is decentralized, they can exert influence through local initiatives to push their agenda. In the UK, however, where politics are more centralized and the power is mainly in the hands of Parliament, it is much harder for smaller interest groups to make their voices heard (Coleman and Carlin 1996). However, as Coleman and Carlin (1996) note, an increasing liberalization of the media and a growing demand for regional autonomy might result in a change of circumstances that is more favourable to creationism. Nevertheless, creationists' efforts to disseminate their beliefs through various media will only be effective to the extent that their message finds a receptive soil. This, again, is determined by a series of other factors, including those discussed above. 
Although some European countries appear to be very successful in warding off creationist activism, the facts discussed above do reveal that creationism has found a distinctive foothold in the European religious landscape. In that regard, several authors have noted the enormous potential of creationism to adapt to local circumstances. According to Edis (1999), the Christian creationism of the ICR was so easily transplanted into an Islamic context because "creationism mobilizes traditional Abrahamic convictions about the moral significance of the natural world against the threat of social modernity." The creationist activists of both the ICR and BAV "answer a need to claim science for the side of old-time social morality, and both correctly see that evolution is a major intellectual obstacle." Inga Levit and colleagues (2007: 16) explain why creationism could become so popular in Russia:

[B]ecause the most important creationist arguments are of a universal anti-scientific nature, they are easily converted into any cultural context and were able therefore to influence the Orthodox creationists, who saw them as useful in their doctrinal attack on secular education.

These examples also hint at the extraordinary talent of creationist activists for identifying people's main moral, social, and political concerns with evolution. In former parts of the Soviet Union, evolution is easily associated with communism, whereas in Muslim communities, it stands for the moral degradation that allegedly comes with Western secularism. By tapping into people's greatest fears, creationists are able to present their beliefs as the ideal remedy against those purported cultural and political maladies.

In the end, however, no single criterion exists by which one can determine why creationist beliefs draw many adherents in one, but not in another region. Whether a factor fosters or hinders the distribution of creationist beliefs very much depends on the local context with which a particular factor interacts. For instance, Roman Catholicism is unfavourable to the dissemination of creationism in western Europe, but seems to offer a fertile soil for creationist beliefs in Poland. Religious education makes students receptive to 
creationist concepts in Germany, whereas in the UK it makes young minds immune to absolute claims. Knowledge of local contexts is therefore essential for understanding the popularity (or lack thereof) in a particular region, and hence local studies are certainly important. However, this does not entail that scholars are restricted to studying those contexts in isolation. Rather, when comparing different contexts, they can determine the manner of interaction of a particular factor with a particular complex of other factors. Our current understanding of creationism in Europe does not allow for such an analysis.

\section{The gaps}

The review above has established at least two important facts about creationist activism in Europe. First, although European creationists are not as well organized as their US counterparts and do not live in large numbers in each European country, they certainly exist and have considerable influence. Moreover, sometimes they are very active and tremendously keen to gain access to political power with the explicit intention of influencing national and European educational policy to their advantage. Second, because people are becoming increasingly aware of the fact that creationist activism is indeed an extant phenomenon, an increasing number of European scholars have taken an interest in this subject. As a result, publications dealing with creationist activism in a particular European country or with European creationism in general have appeared more frequently over the last ten years. However, because the research concerning creationism in Europe is only nascent, it should not come as a surprise that many gaps still need to be addressed in order to arrive at a sufficient understanding of the phenomenon.

What is most apparently absent from the literature is a sustained approach to the subject of creationism in Europe. As to the historical literature, although some papers list a series of creationist incidents that occurred in several European countries, these overviews 
tend to be rather limited and anecdotal. This is due to the fact that they are often written with the intention of giving some indication that creationists are indeed active in Europe. Other papers discuss creationist activism in a particular European country in a little more detail, but these are scattered across different journals and books and are sometimes published in the native language (for instance, in France, see Arnould 1996, 2007; in Denmark, see Hjermitslev 2010a, 2007a; in Germany, see Kutscherz 2007b; Lepeltier 2007), which makes the findings documented in these publications somewhat difficult to access and compare. In addition, as a significant number of local studies are published in newspapers and magazines, they are not systematically registered in scholarly databases. Moreover, authors tend to take different angles, focus on different aspects involving creationism and rarely attempt to put their research in a European context. The most common point of reference is the United States, which is understandable as well as necessary. However, it is problematic if our aim is to attain a proper understanding of creationism in Europe. To that end, we will also need more research on creationism in a greater variety of countries, preferably conducted from a similar perspective. As we have discussed above, the same remark also applies to quantitative studies, as European surveys are sparse, fragmented and methodologically inconsistent.

As long as a uniform approach is lacking in both historical and quantitative studies, a reliable assessment of the distribution of creationist beliefs and activism across Europe will be difficult. However, such an assessment is absolutely necessary when aiming to provide solid explanations for discrepancy in the popularity of creationism in different European countries. These explanatory studies would also, somewhat paradoxically, benefit from a richer diversity in the types of studies that focus on European creationism. For example, scholars of religion could examine the impact of particular religions and theological traditions on the popularity of creationist beliefs and the interaction of religion with other factors. Historians could trace the background and development of arguments, groups and organizations. Anthropologists could 
study the internal organization of creationist groups and produce typical anthropological portraits of creationists from around Europe, while sociologists could generate data on how creationism is related to particular social groups, whether these groups form a minority or not, and how creationist beliefs relate to other beliefs within creationist groups. Educational scientists could identify creationist sympathies among teachers and students, probe for their understanding of evolutionary theory and establish how these factors are related. Legal scholars and political scientists could evaluate the juridical and political background against which European creationist activism can be understood. For more inspiration, European scholars could look across the Atlantic and determine from which angles and in what ways American creationism has been approached and studied. However, such a wide range in perspectives will only be fruitful if, within each type, researchers applied similar methods and focused on the same issues. To sum up, a comprehensive, interdisciplinary understanding of creationism in Europe will not simply be provided by the totalling of all the research studies conducted separately in each European country. Instead, it requires transnational coordination via cooperation both across the European continent and with experienced scholars, research centres and organizations in the United States. Given the linguistic, religious, and financial barriers between European countries, such cooperation might prove complicated, but there is no other option. Only then will the material necessary for a systematic analysis of creationism in Europe become available.

Naturally, a sustained, methodical approach could certainly be enriched by studies that focus on particular European creationist cultures in an attempt to learn and understand what kind of worldviews and reasons motivate particular individuals and groups to adhere to creationist beliefs. Such individual studies might be executed by means of interviews, focus groups, or even by submersion of the researcher into a creationist culture, and could bring to light important personal aspects of creationist beliefs that remain undetected by the abstract 
comparative research proposed above. Similar approaches in the United States have already clearly demonstrated their value (Rosenhouse 2012).

\section{The prospects}

Fortunately, the first promising signs of such transnational forms of cooperation are emerging. Out of discontent with the fragmented status of the research on creationism in Europe, the authors of this paper have taken the initiative to bring together scholars from several European countries for a historical study of creationist activism in Europe. By collecting these studies into a single edited volume entitled The History of Creationism in Europe (forthcoming), we can now for the first time take a comprehensive look at the types of differences in local and national contexts and their effects on the distribution of creationist beliefs and groups. Moreover, this enables us to draw a number of generalizations about (the prospects of) European creationism and the study thereof. Here, we share some of the central findings presented in the book and illustrate them with examples drawn from the same volume.

In order to appreciate the developments of modern creationism in Europe we established with our volume, it might help to assume an explicitly Darwinian perspective and think of activist creationism as a species that is confronted with a new environment. The species has several options: if it finds a friendly environment, it will survive and even flourish without undergoing drastic changes. However, in a harsher environment, it might have to adapt to the particular challenges this environment poses, or, if it is unable to do so, its reproductive success will be severely constrained, possibly leading to its extinction. This line of thinking about creationism is not new. The historical developments of American creationism have repeatedly been described as an organism adapting to the particular juridical context of the United States. In an attempt to circumvent the restrictions posed by the 
establishment clause of the First Amendment of the US Constitution, creationism has adopted an increasingly scientific outlook: biblical creationism first morphed into scientific creationism, which later evolved into intelligent design. Such an approach also aligns with relatively recent developments in the study of cultural change in which the transmission of cultural items is described in evolutionary terms (Mesoudi 2011).

US style creationism does sometimes find a hospitable environment in Europe where it is able to spread without altering much of its original features. For instance, in the Ukraine and Belarus, American Protestants and Pentecostals have capitalized on religious freedom after the breakdown of the Soviet Union, establishing communities that adhere to young-earth creationism. However, as long as creationism is considered an alien belief system directly imported from the US, it remains highly subject to the claim that it is nothing but an American, Protestant or Fundamentalist (or sometimes all three) oddity undeserving of the attention of anyone who takes his or her religion seriously. If creationism retains its particular US style shape and form, it will remain a marginal phenomenon, propagated only by religious minorities such as the Seventh Day Adventists, evangelical churches or Jehovah's Witnesses.

However, when these new churches are able to connect with local churches that have appropriated or accepted creationism as an inherent part of, or at least implied by, their own religious tradition, the odds of success for creationism raise considerably. For instance, in the Netherlands, during the 1970s, American evangelicalism found an ally in the highly conservative reformed churches that were dismayed about the modern and liberal course that mainstream reformed Protestantism had taken in the 1960s. Together, they established their own subculture with its own television and radio network, newspapers and schools, allowing the Dutch to take the lead in propagating creationism in Europe. Today, although Dutch creationism has never managed to cross the boundaries of its own subculture, let alone the 
Dutch borders, in comparison with other European countries, it is still a formidable and prominent movement within the Dutch religious landscape.

Another adaptive strategy for creationism is to associate evolution with phenomena that are considered evil in a particular cultural environment. For instance, in Russia, activist creationists frame the creation-evolution debate in terms of freedom and oppression, thereby explicitly associating evolution with the Communist regime. As such, they can tap into common resentments among the public, thus possibly promoting their cause even among social groups that would generally not sympathize with them. Other concerns of a more general nature, such as the allegedly dramatic moral implications of evolutionary theory or the association of evolution with Social Darwinism, as for instance in the Islamic creationism promoted by Adnan Oktar and his organization, can become attuned to particular local sentiments and interpretations.

However, not many European cultures are that favourable to the American type of creationism. Nonetheless, history proves that it adapts rather easily to the specific culture it finds itself in, a quality that has enabled it to spread quickly across the globe. For instance, in Turkey, where American flood geologists looked for Noah's Ark on Mount Ararat, creationism took on Islamic colors. Since the creation story in the Qur'an is not as specific as in Genesis, they put less emphasis on the age of the Earth. However, many of the features of contemporary Islamic creationism are directly copied from American creationism. In the UK, where there is no First Amendment to worry about, creationists tend to be less concerned with the scientific outlook of their beliefs and put forth the Bible as the source of their antievolutionary views, again distinguishing themselves from American import. In Germany, two members of the creationist organization Studiengemeinschaft Wort und Wissen, Reinhard Junker and Siegfried Scherer, have appropriated typical American creationist arguments 
against evolutionary theory in their Evolution: Ein kritisches Lehrbuch. However, they appear to have succeeded in presenting their ideas as a distinctly European critique of evolution, thus presenting European conservative Christians with the opportunity to question the undesirable aspects of modern biology without running the risk of being associated with Fundamentalism. For instance, in 1999, Joseph Cardinal Ratzinger (later Pope Benedict XVI), explicitly referred to the Scherer and Junker volume as he expressed his doubts about macroevolution (Ratzinger 1999). By evolving into a belief system that fits in with the local religious background, creationism seems to find a receptive audience amongst those that would probably never accept American creationism.

In most European cultural environments, however, competition for creationism is rather tough. It has to deal with exceptionally popular secular and atheist beliefs and liberal theistic views on the Bible and Christian orthodoxy that apparently have no quarrel with modern science. In Flanders, for instance, activist creationism has not been able to gain a foothold because, historically, dominant liberal theological beliefs paved the way for a highly secularized society. In France, anticlerical sentiments have resorted to the same effect. Sometimes, imported creationist beliefs even find themselves in a struggle for survival with other creationist beliefs that have emerged from a local religious tradition. For instance, in Russia, within the Orthodox Church, there is a substantial and influential group of radicals who defend such an indigenous form of creationism, thus seriously constraining the dissemination of American style creationism. However, admittedly, American creationist arguments and strategies are easily assimilated into the local antievolutionary rhetoric, a process one could describe as a cultural variant of horizontal gene transfer. As such, at least some elements of American style creationism are still able to multiply. 
Because of this rich diversity in adaptive strategies evoked by the different European cultural environments, it is impossible to speak of one European creationism. Instead, depending on which country or region one considers, creationism in Europe might take on a scientific outlook or might be deeply anchored in religious beliefs about the inerrancy of the Bible. It might be imported or indigenous, assume a Catholic, Protestant, Muslim, Orthodox or some other identity, and might be accepted by only a small minority or instead be highly popular. It might be regarded as a respectable religious worldview, or labelled as a crank idea. It might stand for a belief in a young or an old earth, or constitute a European version of intelligent design. The only link between all these types is their opposition to evolution, but even then, one can make a distinction between stealth forms of resistance, such as teaching creationism in local schools, and the activist, highly vocal variant that one finds in creationist organizations and publications. For now, it is impossible to predict the future of each form of creationism. Nonetheless, by examining how creationism responds, or fails to respond, to the variety of European cultural contexts, one can learn a great deal about the conditions under which this particular cultural species flourishes or becomes extinct. As such, the study of creationism in Europe, with its unique cultural diversity, can make a highly important contribution to the study of creationism in general.

However, the potential of insight of such a study reaches far beyond its original subject. As creationism constitutes an important, yet often neglected, aspect of the European religious landscape, a better understanding of creationism in Europe, both in its activist and intuitive form will add substantially to the study of religion. Furthermore, as creationism involves particular negative negotiations of established scientific theories, the study will also shed light on the historical relation between science and religion. In this tradition, scholars have proposed that this relationship is complex, often mediated by specific local factors (Livingstone 1999, 2009), which is a thesis that can be tested and further developed in 
application to creationism in Europe. In addition, the study of creationism in Europe will improve the understanding of cultural evolution in general. Philosophers (Blancke and De Smedt forthcoming) and cognitive scientists (Evans 2000) have argued that creationism holds much more intuitive appeal to the human mind than evolutionary theory does, because creationist beliefs tap into our natural predilections for essentialist, teleological and intentional modes of thinking. Given these content biases, one would expect that, all other factors being equal, cultural evolution should converge on a preference for creationist beliefs (Sperber 1996). However, creationism is not as widespread in Europe as in the US and receives much more support in one country than in another. Factors explaining this discrepancy might involve context biases, by which people prefer to learn from prestigious individuals (prestige bias) or simply copy beliefs from the majority (conformity bias) (Boyd and Richerson 2005; Mesoudi 2011). Moreover, contextual factors, which can be of an economic, social, political, psychological, religious, historical or philosophical nature, are also important, for they constitute a cultural ecology that makes other kinds of belief more relevant (Sperber, 1996). Hence, it will not only be important to rely on the findings the range of scientific research domains studying these factors may provide, as these domains themselves would certainly be enriched by studying creationism in Europe.

One important methodological lesson one can draw from the discussion of creationism in Europe, is that, in order to avoid confusion, scholars should distinguish between intuitive, local and imported creationism. Intuitive creationism comprises the set of creationist beliefs people adhere to without explicating, defending or propagating them. Because it usually does not come to the surface and make itself known in the public sphere, this type of creationism is the hardest to trace, even though further quantitative studies would be illuminating in this context. Local and imported types of activist creationism can tap into these creationist intuitions, especially when people perceive (or are made to perceive) evolutionary theory as a 
threat to cherished beliefs or values. Local creationism is the type of activist creationism that emerges from local religious contexts, whereas imported creationism is activist creationism that has been brought into European countries, usually by American or Turkish creationists. Thus, study of creationism in Europe can only be truly successful if it attends to the manner in which the three types of creationism interconnect, against the background of the variety of the aforementioned contextual factors.

\section{Conclusions}

Activist creationism, both local and imported, has been on the rise in Europe for the last fifteen years. The number of scholars dealing with this subject has increased concomitantly, and their interest has resulted in a growing list of publications, which have provided not only historical and quantitative data, but also tried to identify reasons behind the popularity of creationism (or lack thereof). However, a more uniform approach would allow for much needed comparative studies that would allow tracing the impact of the different cultural environments on the evolution and distribution of creationist beliefs. A first sustained historical study demonstrates that there is no such thing as a European creationism, but rather a more generic form that adapts with varying success to the local context it encounters. Further studies of this phenomenon would result in a comprehensive understanding of creationism in Europe and elsewhere, a corpus of knowledge from which researchers from a range of academic domains would benefit. However, this corpus can only be attained through international cooperation between scholars and research groups in both Europe and the United States.

\section{References}

Allgaier, Joachim 
2010 "Scientific Experts and the Controversy About Teaching Creation/Evolution in the UK Press" Science \& Education 19/6: 797819.

2012 "Networking expertise: Discursive coalitions and collaborative networks of experts in a public creationism controversy in the UK" Public Understanding of Science 21/3: 299-313.

Allgaier, Joachim and Holliman, Richard

2006 "The emergence of the controversy around the theory of evolution and creationismin UK newspaper reports" Curriculum Journal 17/3: 263279.

Arnould, Jacques

1996 Les créationnistes, Paris, France: Cerf/Fides.

2007 Dieu versus Darwin. Les créationnistes vont-ils triompher de la science?, Paris, France: Albin Michel.

Blancke, Stefaan

2009 "Exporting creationism: Dutch creationist leaflet now to be distributed in Belgium" Reports of the National Center for Science Education 29/5: 7-9.

2010 "Creationism in the Netherlands" Zygon: Journal of Religion and Science 45/4: 791-816.

Blancke, Stefaan and De Smedt, Johan

2013 "Evolved to be irrational? Evolutionary and cognitive foundations of pseudosciences" In The philosophy of pseudoscience, ed. Massimo Pigliucci and Maarten Boudry, 361-379. Chicago, IL: The University of Chicago Press.

Borczyk, Bartosz

2010 "Creationism and the Teaching of Evolution in Poland" Evolution: Education and outreach 3/4: 614-620.

Boyd, Robert and Richerson, Peter J.

2005 The origin and evolution of cultures, Oxford, UK: Oxford University Press.

British Council 
Cleaves, Anna and Toplis, Rob

2007 "In the shadow of Intelligent Design: the teaching of evolution" Journal of Biological Education 42/1: 30-35.

Clément, Pierre and Quessada, Marie-Pierre

2009 "Creationist Beliefs in Europe" Science 324/5935: 1644.

Clément, Pierre, Quessada, Marie-Pierre, Laurent, Charline and Carvalho, Graça

2008 "Science and religion: evolutionism and creationism in education. A survey of teachers conceptions in 14 countries" In XIII IOSTE Symposium. The use of science and technology education for peace and sustainable development, 1148-1155.Ankara, Turkey: Palme Publications and Bookshops.

Coleman, Simon and Carlin, Leslie

1996 "No contest: the non-debate between creationism and evolutionary theory in Britain" Creation/Evolution 16/1: 1-9.

2004 "Introduction" In The cultures of creationism. Anti-evolutionism in English-speaking countries, ed. Simon Coleman and Leslie Carlin, 128. Aldershot, UK: Ashgate.

Committee on Culture, Science and Education. Parliamentary Assembly. Council of Europe

2007 "Doc. 11297. The dangers of creationism in education." http://assembly.coe.int/ASP/Doc/XrefViewHTML.asp?FileID=11678\& Language $=\mathrm{EN}$

Cornish-Bowden, Athel and Càrdenas, María Luz

2007 "The threat from creationism to the rational teaching of biology" Biological Research 40/2: 113-122.

Curry, Andrew

2009 “Creationist Beliefs Persist in Europe” Science 323/5918: 1159.

Edis, Taner

1994 "Islamic creationism in Turkey" Creation/Evolution 14/1: 1-12. 

Science Education 19/6: 30-35.

European Commission

2005

"Special Eurobarometer. Europeans, Science and Technology." http://ec.europa.eu/public_opinion/archives/ebs/ebs_224_report_en.pdf

Evans, E. Margaret

2000 "Beyond Scopes. Why creationism is here to stay" In Imagining the impossible: Magical, scientific and religious thinking in children, ed. Karl S. Rosengren, Carl N. Johnson and Paul L. Harris, 305-331. Cambridge, MA: Cambridge University Press.

Eve, Raymond A. and Harrold, Francis B.

1991 The creationist movement in modern America, Boston, MA: Twayne.

Flipse, Abraham C.

2012 "The Origins of Creationism in the Netherlands: The Evolution Debate among Twentieth-Century Dutch Neo-Calvinists" Church History. Studies in christianity and culture 81/1: 1-41.

Forrest, Barbara and Gross, Paul R.

2007 [2004] Creationism's Trojan horse. The wedge of Intelligent Design, New York, NY: Oxford University Press.

Fulljames, Peter and Francis, Leslie

2004 "Creationism among young people in Kenya and Britain” In The cultures of creationism: Anti-evolutionism in English-speaking countries, ed. Simon Coleman and Leslie Carlin, 165-173. Aldershot, UK: Ashgate.

Graebsch, Almut and Schiermeier, Quirin

2006 "Anti-evolutionists raise their profile in Europe" Nature 444/7121: 803.

Gross, M. R266. 
Hameed, Salman

2008 "Science and religion. Bracing for Islamic Creationism" Science 322/5908: 1637-1638.

2010 "Evolution and creationism in the Islamic world" In Science and religion: New historical perspectives, ed. Thomas Dixon, Geoffrey Cantor and Stephen Pumfrey, 133-152. Cambridge, UK: Cambridge University Press.

Hassan, Riaz

2007 "On being religious: Patterns of religious commitment in Muslim societies" Muslim World 97/3: 437-478.

Hjermitslev, Hans Henrik

2010a "Dansk kreationisme" Religion 1: 17-27.

2010b "Marginalized and Moderate: The Current Status of Creationism in Denmark and the History of why Antievolutionism Has Never Gained Ground among Mainline Danish Protestants" Paper presented at the Religion in global perspective. Society for the Scientific Study of Religion Annual Meeting. Baltimore, MD.

2011 "Protestant Responses to Darwinism in Denmark, 1859-1914" Journal of the History of Ideas 72/2: 279-303.

Ipsos Global @ dvisory

2011 "Supreme being(s), the afterlife and evolution." http://www.ipsos-na.com/download/pr.aspx?id=10670

Kjærgaard, Peter C.

2008

"Western front" New Humanist 123/3: 39-41.

2010 "The Darwin enterprise: from scientific icon to global product" History of Science 48/159: 105-122.

Kutschera, Ulrich

2003 "Darwinism and Intelligent Design: the new anti-evolutionism spreads in Europe" Reports of the National Center for Science Education 23/56: 5-6.

2006 "Devolution and dinosaurs: the anti-evolution seminar in the European Parliament" Reports of the National Center for Science Education 26/5: $10-11$. 
2007a Kreationismus in Deutschland. Fakten und Analysen, Berlin, Germany: LIT.

2007b Streitpunkt Evolution. Darwinismus und Intelligentes Design, Berlin, Germany: LIT.

2008a "Creationism in Germany and its possible cause" Evolution. Education and outreach 1/1: 84-86.

2008b "The German anti-Darwin industry: Twentieth anniversary of a multimedia business" Reports of the National Center for Science Education 28/1: 12-13.

Larson, Edward J.

2006 Summer of the gods. The Scopes trial and America's continuing debate over science and religion, New York, NY: Basic Books.

Lepeltier, Thomas

2007 Darwin hérétique. L'éternel retour du créationnisme, Paris, France: Seuil.

Levit, Georgy S., Hoßfeld, Uwe and Olsson, Lennart

2006 "Creationists attack secular education in Russia" Nature 444: 265.

Levit, Inga, Hoßfeld, Uwe and Olsson, Lennart

2007 "Creationism in the Russian educational landscape" Reports of the National Center for Science Education 27/5-6: 13-17.

Livingstone, David N.

1999 "Science, region, and religion: the reception of Darwinism in Princeton, Belfast, and Edinburgh" In Disseminating Darwinism. The role of place, race, religion, and gender, ed. Ronald L. Numbers and John Stenhouse, 7-38. Cambridge, UK: Cambridge University Press.

2009 "Evolution and religion" In Evolution. The first four billion years, ed. Michael Ruse, 348-369. Cambridge, MA: Belknap Press of Harvard University Press.

Locke, Simon

2004 "Creationist discourse and the management of political-legal discourse" In The cultures of creationism. Anti-evolutionism in English-speaking 
countries, ed. Simon Coleman and Leslie Carlin, 45-65. Aldershot, UK: Ashgate.

Mackenzie Brown, C.

2010 "Hindu responses to Darwinism: assimilation and rejection in a colonial and post-colonial context" Science \& Education 19/6: 705-738.

McCalla, Arthur

2006 The creationist debate. The encounter between the Bible and the historical mind, London, UK and New York, NY: Continuum.

McCrory, Conor and Murphy, Colette

2009 "The Growing Visibility of Creationism in Northern Ireland: Are New Science Teachers Equipped to Deal with the Issues?" Evolution: Education and outreach 2/3: 372-385.

Mesoudi, Alex

2011 Cultural evolution. How Darwinian theory can explain human culture and synthesize the social sciences, Chicago, IL: Chicago University Press.

Miller, Jon D., Scott, Eugenie C. and Okamoto, Shinji

2006 “Public acceptance of evolution” Science 313/5788: 765-766.

Numbers, Ronald L.

2006 The creationists. From scientific creationism to Intelligent Design, Cambridge, MA: Harvard University Press.

2009 "Myth 24. That creationism is a uniquely American phenomenon" In Galileo goes to jail and other myths about science and religion, ed. Ronald L. Numbers, 215-223. Cambridge, MA: Harvard University Press.

2011 "Clarifying creationism: five common myths" History and Philosophy of the Life Sciences 33/1: 129-139.

Parliamentary Assembly of the Council of Europe

2007 "Resolution 1580. The dangers of creationism in education." http://assembly.coe.int/main.asp?link=/documents/adoptedtext/ta07/eres $\underline{1580 . h t m}$ 
Ratzinger, Joseph Cardinal

1999 "Die Christenheit, die Entmythologisierung und der Sieg der Warheit über die Religionen," http://ivv7srv15.unimuenster.de/mnkg/pfnuer/Ratzinger-Wahrheit.html, accessed on 1 February 2013.

Riexinger, Martin

2008 "Propagating Islamic creationism on the internet" Masaryk University Journal of Law and Technology 2/2: 99-112.

2010 "Islamic opposition to the Darwinian theory of evolution" In Handbook of religion and the authority of science, ed. James R. Lewis and Olav Hammer, 483-510. Leiden, the Netherlands: Brill.

Rosenhouse, Jason

2012 Among the creationists. Dispatches from the anti-evolutionist front line, New York, NY: Oxford University Press.

Sayin, Ümit and Kence, Aykut

1999 "Islamic scientific creationism" Reports of the National Center for Science Education 19/6: 18-20, 25-29.

Sperber, Dan

1996 Explaining culture. A naturalistic approach, Oxford, UK: Blackwell.

Szerszynski, Bronislaw

2010 "Understanding creationism and evolution in America and Europe" In Science and religion. New historical perspectives, ed. Thomas Dixon, Geoffrey Cantor and Stephen Pumfrey, 153-174. Cambridge, UK:

Cambridge University Press.

Williams, James

2008 "Creationist Teaching in School Science: A UK Perspective" Evolution: Education and outreach 1/1: 87-95. 